Article

\title{
Waddlia chondrophila and Male Infertility
}

\author{
David Baud $^{1,+}{ }^{1}$, Nicolas Vulliemoz ${ }^{2, \dagger}$, Maria Verónica Morales Zapata ${ }^{1}$, Gilbert Greub ${ }^{3}$ (D) \\ Manon Vouga ${ }^{1}$ and Milos Stojanov ${ }^{1, *(D)}$ \\ 1 Materno-Fetal and Obstetrics Research Unit, Department Woman-Mother-Child, Lausanne University \\ Hospital, 1011 Lausanne, Switzerland; David.Baud@chuv.ch (D.B.); \\ Maria-Veronica.Morales-Zapata@chuv.ch (M.V.M.Z.); Manon.Vouga@chuv.ch (M.V.) \\ 2 Fertility Medicine and Gynaecologic Endocrinology Unit, Department Woman Mother Child, Lausanne \\ University Hospital, 1011 Lausanne, Switzerland; Nicolas.Vulliemoz@chuv.ch \\ 3 Institute of Microbiology, Lausanne University Hospital and University of Lausanne, 1011 Lausanne, \\ Switzerland; Gilbert.Greub@chuv.ch \\ * Correspondence: milos.stojanov@chuv.ch \\ + Shared first authorship.
}

Received: 29 November 2019; Accepted: 16 January 2020; Published: 17 January 2020

\begin{abstract}
Waddlia chondrophila, a Chlamydia-like bacterium, has been previously associated with adverse pregnancy outcomes. Analogously to Chlamydia trachomatis, $W$. chondrophila also negatively impacts human semen and may be a source of impaired male fertility. In this study, we analyzed $W$. chondrophila seroprevalence in a population of male patients of infertile couples and the impact of past exposition to this bacterium on semen parameters. Our results show a surprisingly high seroprevalence of $W$. chondrophila, which contrasts with a previous study focusing on a population of healthy men. Nevertheless, we did not observe any significant association between positive serology and abnormal sperm parameters. This may suggest that a negative impact on semen is observed only during an ongoing infection. Alternatively, $W$. chondrophila may have an immune impact on male fertility, as previously postulated for women with adverse pregnancy outcomes.
\end{abstract}

Keywords: Waddlia; chlamydia-like; male infertility; semen

\section{Introduction}

Since the 1980s, a concerning decrease in semen quality has been reported, and potential causes are still being debated [1,2]. Etiologies, including endocrine and genetic disorders, have been demonstrated [3], but male infertility may be linked to environmental factors. Lifestyle habits, such as smoking, high BMI, and the increasing exposure to xenoestrogens, for example in drinking water, have been associated with reduced male fertility [4,5]. An additional hypothesis is that silent and/or chronic bacterial infections of the genital tract causing inflammation and direct deterioration of semen might partially explain some of the otherwise idiopathic cases [3,6-8]. The well-known intracellular pathogen, Chlamydia trachomatis, which can cause urethritis and negatively impact spermatozoa physiology, may be a key example [9-12].

Using an in vitro model of infection, we recently showed that Waddlia chondrophila, an emerging Chlamydia-like bacterium, has a negative impact on human spermatozoa [13]. By analogy with C. trachomatis, W. chondrophila was able to attach and penetrate into spermatozoa, reducing their viability and mitochondrial membrane potential, which is linked to motility. Moreover, standard sperm washing techniques were unable to completely eradicate it.

$W$. chondrophila was first isolated from samples of aborted bovine fetuses [14,15]. This raised concerns for a potential abortigenic agent for other mammals, including humans. Three independent prospective serology based studies indicated that $W$. chondrophila might act as a possible inducer of 
miscarriage in pregnant women [16-18]. Moreover, W. chondrophila was shown to replicate in several human cell lines including fibroblasts, peripheral blood mononuclear cells, A549 pneumocytes, and in Ishikawa endometrial cells $[14,19,20]$. The seroprevalence of anti- $W$. chondrophila antibodies was significantly higher in women who experienced miscarriages compared to control groups of women with uneventful pregnancies. This association remained significant even after correction for age, ethnicity, and $C$. trachomatis serology status and was not due to cross-reactivity with other microorganisms known to induce pregnancy loss, such as C. trachomatis, Coxiella burnetti, Toxoplasma gondii, Brucella abortus, and Parachlamydia acanthamoebae [16]. Presence of W. chondrophila in human samples (placenta, vaginal swab, urine) was subsequently documented by PCR and/or immunohistochemistry [17].

Despite multiple reports of association with adverse pregnancy outcomes and the negative effect on human spermatozoa, it is not known whether W. chondrophila is associated with a deleterious effect on the male genital tract. This study aims to analyze whether this bacterium could be linked with reproductive disorders in men, namely men of infertile couples.

\section{Material and Methods}

\subsection{Samples}

Serum and sperm samples were collected from men of infertile couples seeking infertility investigations at the Fertility Medicine Unit (Lausanne University Hospital, Lausanne, Switzerland). This study was carried out in accordance with the recommendations of the Cantonal Human Research Ethics Commission of Vaud (CER-VD)( protocol 265/14), according to the Swiss Federal Act on Research involving Human Beings. The study protocol was approved by the commission (protocol 265-14). All patients were fully informed about the content of the research project and gave their written consent to be included in the study.

Semen assessment was performed in the Laboratory of Andrology and Reproductive Biology (LABR, Lausanne University Hospital, Switzerland). Semen was obtained by masturbation after 2 to 5 days of sexual abstinence. After a $30 \mathrm{~min}$ liquefaction at $37^{\circ} \mathrm{C}$, samples were manually assessed for volume, $\mathrm{pH}$, and morphology using the Papanicolaou method. CASA SCA (Version 5.4, Microptic SL, Barcelona, Spain) computer-assisted sperm analysis software was used to evaluate sperm concentration and motility (total and progressive). All analyses were performed following the 2010 World Health Organization laboratory manual for the examination and processing of human semen guidelines (5th edition).

\subsection{Microimmunofluorescence}

Serology for $W$. chondrophila was performed as described previously [16,21]. Briefly, formalininactivated W. chondrophila strain ATCC VR-1470 was deposited on serology slides as an antigen. Serum samples were serially diluted in phosphate-buffered saline, and dilutions of 1/32 and 1/64 were included in the analysis. Mouse anti-human IgG secondary antibody conjugated to Alexa Fluor 488 dye (Thermo Fisher Scientific, Allschwil, Switzerland, diluted 1/1000) was used to detect the presence of anti-W. chondrophila IgG.

Microimmunofluorescence tests were analyzed by two independent evaluators. Weighted Cohen's kappa coefficient was determined for each series to assess the agreement of the results and always ranked between "good" and "very good". In cases of discrepancy, a third evaluator was involved, and the case was discussed to reach consensus.

\subsection{Enzyme-Linked Immunosorbent Assay (ELISA)}

Serology for C. trachomatis was performed with the "Anti-Chlamydia trachomatis ELISA (IgG)" (EI 2191-9601 G, EUROIMMUN Schweiz AG, Luzern, Switzerland), according to the manufacturer's indications. 


\subsection{DNA Extraction from Sperm Samples and Real-Time Quantitative Polymerase Chain Reaction Assay (qPCR)}

DNA was extracted from $1 \mathrm{~mL}$ of semen using the QIAamp DNA mini kit (Qiagen AG, Basel, Switzerland) following the manufacturer's specifications with the addition of $43 \mathrm{mM}$ DTT to the lysis buffer as the sole modification. All samples were analyzed using a $W$. chondrophila-specific qPCR and a Chlamydiales-specific qPCR, as previously described [22,23].

\subsection{DNA Sequencing and Analysis}

DNA sequencing was performed by Eurofins Genomics (Eurofins Genomics GmbH, Kostanz, Germany), with the primers used for the Chlamydiales-specific qPCR [23]. Obtained sequences were manually trimmed and blasted against the NCBI nr/nt database (partially non-redundant nucleotide sequences from GenBank, EMBL, and DDB, analysis performed on September 2019) using the blast module of the Geneious prime software (version 2020.1, Biomatters Limited, Auckland, New Zealand). For each positive sample, the top hit from the blast analysis was presented in Table 1.

Table 1. Chlamydiales bacteria detected in the semen samples.

\begin{tabular}{|c|c|c|c|c|c|c|c|}
\hline Sample & Hit & $\begin{array}{c}\text { Accession } \\
\text { Number }\end{array}$ & $\begin{array}{l}\text { Identity } \\
(\%)\end{array}$ & $\begin{array}{l}\text { Alignment } \\
\text { Length } \\
\text { (bp) }\end{array}$ & $\begin{array}{c}\text { W. } \\
\text { chondrophila } \\
\text { Serology }\end{array}$ & $\begin{array}{c}\text { C. } \\
\text { trachomatis } \\
\text { Serology }\end{array}$ & Spermiogram \\
\hline 1 & $\begin{array}{l}\text { Uncultured } \\
\text { Chlamydiales } \\
\text { bacterium } \\
\text { clone } 14-41\end{array}$ & KX451108 & 96.8 & 156 & Pos & Neg & Abnormal \\
\hline 7 & $\begin{array}{l}\text { Uncultured } \\
\text { Chlamydiales } \\
\text { bacterium } \\
\text { clone } 12-15\end{array}$ & KX451048 & 95.7 & 162 & Pos & Neg & Abnormal \\
\hline 10 & $\begin{array}{l}\text { Uncultured } \\
\text { Chlamydiales } \\
\text { bacterium } \\
\text { clone 14-02 }\end{array}$ & JX083073 & 91.4 & 175 & Pos & Neg & Abnormal \\
\hline 135 & $\begin{array}{l}\text { Uncultured } \\
\text { Chlamydiales } \\
\text { bacterium } \\
\text { clone } \\
\text { HE210001biof }\end{array}$ & JX083106 & 94.9 & 78 & Pos & Neg & Normal \\
\hline 222 & $\begin{array}{c}\text { Uncultured } \\
\text { Chlamydiales } \\
\text { bacterium } \\
\text { clone AHDr12 }\end{array}$ & JQ860021 & 100 & 181 & Pos & Neg & Abnormal \\
\hline 239 & $\begin{array}{c}\text { Uncultured } \\
\text { Chlamydiales } \\
\text { bacterium } \\
\text { clone AHDr12 }\end{array}$ & JQ860021 & 100 & 181 & Pos & Neg & Abnormal \\
\hline
\end{tabular}

\subsection{Statistical Analysis}

Statistical analysis was performed with RStudio Version 1.2.1335 (RStudio, Inc., Boston, MA, USA). Categorical variables were compared using the Pearson $\chi 2$ test, while continuous variables were compared using the Wilcoxon-Mann-Whitney test. A $p$-value $<0.05$ was considered statistically significant.

\section{Results}

A total of 204 men of infertile couples were enrolled in the study, and their semen parameters were evaluated using the WHO guidelines. The impact of $W$. chondrophila on semen parameters was assessed by performing serological analysis on the serum samples. A total of $58.3 \%$ of patients had W. chondrophila-specific IgG, indicating a previous exposure to the microorganism. Our results indicated that positive serology was not significantly associated with abnormal semen status (Tables 2 and 3 ). In addition, seropositivity was not linked to a reduced value of specific spermiogram parameters, including 
total spermatozoa count and concentration, total motility, progressive motility, and morphology (Table 2). Similar results were observed for C. trachomatis, although seroprevalence was lower in this case (Table 2). Interestingly, we observed an association with patient age, as the group with positive serology (1/32) was significantly older compared to men with negative serology (Table 2).

Table 2. Characteristics of patients according to W. chondrophila serology.

\begin{tabular}{|c|c|c|c|c|c|c|}
\hline \multirow{2}{*}{ Characteristics } & \multicolumn{3}{|c|}{ W. chondrophila Serology 1/32 } & \multicolumn{3}{|c|}{ W. chondrophila Serology 1/64 } \\
\hline & $\begin{array}{c}\text { Negative } \\
n=85\end{array}$ & $\begin{array}{c}\text { Positive } \\
n=119\end{array}$ & $p$-Value & $\begin{array}{c}\text { Negative } \\
n=106\end{array}$ & $\begin{array}{c}\text { Positive } \\
n=98\end{array}$ & $p$-Value \\
\hline \multicolumn{7}{|c|}{ Demographic characteristics } \\
\hline Age (years) & $35.9 \pm 7.0$ & $38.0 \pm 6.1$ & 0.005 & $36.9 \pm 7.2$ & $37.4 \pm 5.8$ & 0.322 \\
\hline$<30$ & 20 & 11 & 0.005 & 20 & 11 & 0.185 \\
\hline$>30$ & 65 & 108 & & 86 & 87 & \\
\hline \multicolumn{7}{|l|}{ Origin } \\
\hline Swiss & 39 & 58 & 0.687 & 52 & 45 & 0.758 \\
\hline Non-swiss & 46 & 61 & & 54 & 53 & \\
\hline \multicolumn{7}{|l|}{ Origin partner } \\
\hline Swiss & 33 & 38 & 0.308 & 41 & 30 & 0.289 \\
\hline Non-swiss & 52 & 81 & & 65 & 68 & \\
\hline \multicolumn{7}{|l|}{ Education } \\
\hline University & 21 & 29 & 0.956 & 28 & 22 & 0.621 \\
\hline Non-university & 64 & 90 & & 78 & 76 & \\
\hline \multicolumn{7}{|l|}{ Place of residence } \\
\hline City & 66 & 81 & 0.133 & 77 & 70 & 0.971 \\
\hline Rural & 19 & 38 & & 29 & 28 & \\
\hline \multicolumn{7}{|l|}{ Pets } \\
\hline Yes & 26 & 38 & 0.838 & 36 & 28 & 0.498 \\
\hline No & 59 & 81 & & 70 & 70 & \\
\hline \multicolumn{7}{|l|}{ Serology (IgG) } \\
\hline \multicolumn{7}{|l|}{ C. trachomatis serology } \\
\hline Neg & 72 & 98 & 0.657 & 88 & 82 & 0.950 \\
\hline Pos & 13 & 21 & & 18 & 16 & \\
\hline \multicolumn{7}{|l|}{ Semen characteristics } \\
\hline \multicolumn{7}{|l|}{ Spermiogram } \\
\hline Normal & 18 & 29 & 0.593 & 24 & 23 & 0.888 \\
\hline Abnormal & 67 & 90 & & 82 & 75 & \\
\hline \multicolumn{7}{|c|}{ Sperm concentration $\left(\times 10^{6} / \mathrm{mL}\right)$} \\
\hline Mean & 37.53 & 39.88 & 0.862 & 38.59 & 39.24 & 0.815 \\
\hline $\mathrm{SD}$ & 42.85 & 39.48 & & 41.69 & 40.09 & \\
\hline \multicolumn{7}{|l|}{ Total sperm count $\left(\times 10^{6}\right)$} \\
\hline Mean & 112.06 & 116.31 & 0.867 & 109.7 & 119.77 & 0.879 \\
\hline $\mathrm{SD}$ & 115.75 & 122.11 & & 110.26 & 128.6 & \\
\hline \multicolumn{7}{|l|}{ Total motility (\%) } \\
\hline Mean & 53.44 & 52.69 & 0.841 & 52.82 & 53.19 & 0.864 \\
\hline SD & 23.22 & 23.74 & & 23.45 & 23.6 & \\
\hline \multicolumn{7}{|l|}{ Progressive motility (\%) } \\
\hline Mean & 37.65 & 36.44 & 0.775 & 37.26 & 36.59 & 0.992 \\
\hline SD & 18.77 & 18.12 & & 18.86 & 17.88 & \\
\hline \multicolumn{7}{|l|}{ Sperm morphology (\%) } \\
\hline Mean & 2.52 & 2.91 & 0.343 & 2.61 & 2.89 & 0.546 \\
\hline SD & 2.27 & 2.51 & & 2.31 & 2.53 & \\
\hline \multicolumn{7}{|l|}{ Clinical history } \\
\hline Andrological issues & & & & & & \\
\hline Yes & 9 & 13 & 0.939 & 11 & 11 & 0.845 \\
\hline No & 76 & 106 & & 95 & 87 & \\
\hline Obstetrical issues (partn & & & & & & \\
\hline Yes & 35 & 37 & 0.137 & 44 & 28 & 0.074 \\
\hline No & 50 & 82 & & 62 & 70 & \\
\hline Miscarriages (partner) & & & & & & \\
\hline Yes & 32 & 32 & 0.103 & 39 & 25 & 0.241 \\
\hline No & 53 & 87 & & 67 & 73 & \\
\hline
\end{tabular}


Table 3. Characteristics of patients according to semen parameters.

\begin{tabular}{|c|c|c|c|}
\hline \multirow{2}{*}{ Characteristics } & \multicolumn{3}{|c|}{ Sperm Parameters } \\
\hline & $\begin{array}{c}\text { Normal } \\
n=47\end{array}$ & $\begin{array}{c}\text { Abnormal } \\
n=157\end{array}$ & $p$-Value \\
\hline \multicolumn{4}{|c|}{ Demographic characteristics } \\
\hline Age (years) & $37.2 \pm 7.2$ & $37.1 \pm 6.4$ & 0.899 \\
\hline$<30$ & 8 & 23 & 0.691 \\
\hline$>30$ & 39 & 134 & \\
\hline \multicolumn{4}{|l|}{ Origin } \\
\hline Swiss & 30 & 67 & 0.011 \\
\hline Non-swiss & 17 & 90 & \\
\hline \multicolumn{4}{|l|}{ Origin partner } \\
\hline Swiss & 20 & 51 & 0.204 \\
\hline Non-swiss & 27 & 106 & \\
\hline \multicolumn{4}{|l|}{ Education } \\
\hline University & 15 & 35 & 0.179 \\
\hline Non-university & 32 & 122 & \\
\hline \multicolumn{4}{|l|}{ Place of residence } \\
\hline City & 36 & 111 & 0.429 \\
\hline Rural & 11 & 46 & \\
\hline \multicolumn{4}{|l|}{ Pets } \\
\hline Yes & 17 & 47 & 0.419 \\
\hline No & 30 & 110 & \\
\hline \multicolumn{4}{|l|}{ Serology } \\
\hline \multicolumn{4}{|l|}{ W. chondrophila serology } \\
\hline Neg & 18 & 67 & 0.593 \\
\hline Pos & 29 & 90 & \\
\hline \multicolumn{4}{|l|}{ C. trachomatis serology } \\
\hline Neg & 37 & 133 & 0.334 \\
\hline Pos & 10 & 24 & \\
\hline \multicolumn{4}{|l|}{ Semen characteristics } \\
\hline \multicolumn{4}{|c|}{ Sperm concentration $\left(\times 10^{6} / \mathrm{mL}\right)$} \\
\hline Mean & 80.43 & 26.47 & $<0.001$ \\
\hline $\mathrm{SD}$ & 43.43 & 30.63 & \\
\hline \multicolumn{4}{|l|}{ Total perm count $\left(\times 10^{6}\right)$} \\
\hline Mean & 231.69 & 79.47 & $<0.001$ \\
\hline SD & 123.05 & 93.06 & \\
\hline \multicolumn{4}{|l|}{ Total motility (\%) } \\
\hline Mean & 75.77 & 46.18 & $<0.001$ \\
\hline $\mathrm{SD}$ & 12.02 & 21.71 & \\
\hline \multicolumn{4}{|l|}{ Progressive motility (\%) } \\
\hline Mean & 54.85 & 31.58 & $<0.001$ \\
\hline $\mathrm{SD}$ & 11.55 & 16.54 & \\
\hline \multicolumn{4}{|l|}{ Sperm morphology (\%) } \\
\hline Mean & 5.47 & 1.93 & $<0.001$ \\
\hline SD & 1.8 & 1.93 & \\
\hline \multicolumn{4}{|l|}{ Clinical history } \\
\hline \multicolumn{4}{|l|}{ Andrological issues } \\
\hline Yes & 5 & 17 & 0.971 \\
\hline No & 42 & 140 & \\
\hline \multicolumn{4}{|l|}{ Obstetrical issues (partner) } \\
\hline Yes & 20 & 52 & 0.235 \\
\hline No & 27 & 105 & \\
\hline Miscarriages (partner) & & & \\
\hline Yes & 31 & 109 & 0.653 \\
\hline No & 16 & 48 & \\
\hline
\end{tabular}


Given the high exposure to the bacterium, we wanted to evaluate whether $W$. chondrophila actively colonizes sperm of patients included in the study. Total DNA was extracted from semen samples and analyzed with a specific qPCR, which indirectly shows presence of the bacteria in the sample. None of the samples tested positive for $W$. chondrophila DNA. For this reason, we did not attempt the isolation of the bacterium from semen.

To analyze the presence of Chlamydia-like bacteria more broadly, samples were additionally tested with a Chlamydiales-specific qPCR. A total of $2.9 \%(n=6)$ of samples were positive with qPCR analysis, and their amplified DNA was purified, sequenced, and compared to sequences present in nucleotide sequence databases. Top hits obtained by blast analysis with the highest identity and alignment lengths are shown in Table 1. Interestingly, five of these six patients had abnormal semen parameters.

\section{Discussion}

Multiple serological studies have demonstrated an association of the intracellular bacterium W. chondrophila with adverse pregnancy outcomes. Most studies have targeted female patients, while seroprevalence of $W$. chondrophila in men has only been investigated on two occasions, until now. In the first study, $13.7 \%$ of healthy young Swiss men (66 out of 482) attending military service tested positive [24], while in the second, this was the case for $45 \%$ (18 out of 40) of Israeli men [25].

We have previously shown that human spermatozoa exposed to $W$. chondrophila displayed a reduction of viability and mitochondrial membrane potential [13]. Therefore, this study focused on a population of men of infertile couples in order to address whether exposure to this bacterium negatively impacts male fertility.

Interestingly, we observed a high seroprevalence of $58.3 \%$, which is higher compared to all previous serology studies, including those with women who experienced adverse pregnancy outcomes [16-18]. On the contrary, we did not detect $W$. chondrophila DNA, indicating that this bacterium might not colonize semen. The high seroprevalence and absence by qPCR detection may be explained by multiple scenarios. For example, (a) infection may have occurred in the past, and thus the qPCR is negative; (b) the infection is ongoing, but in a body site other than the male reproductive system; (c) the infection occurred in the past in another body site.

One important limitation of our study is the absence of a control population consisting of men with proven fertility, which was not explored due to ethical aspects and the difficulty of obtaining semen in healthy individuals. Moreover, we cannot rule out the presence of PCR inhibitors in DNA extracted from semen, which could inhibit the W. chondrophila-specific qPCR. Nevertheless, our previous study showed that this bacterium could be detected within artificially infected sperm samples by the same qPCR [13].

Similar studies performed with C. trachomatis, which was also included in our study, gave highly variable outcomes [26-28]. It is still not clear if and how C. trachomatis impacts male fertility, although it can cause epididymitis, urethritis, and prostatitis, all of which might lead to an impairment of reproductive potential [3,29]. Moreover, it can have a direct negative effect on spermatozoa physiology [10,30-32], as shown in vitro for W. chondrophila [13]. In the present clinical study, we did not observe any significant association with abnormal semen parameters in males that tested positive for W. chondrophila. Male seropositivity was not associated with adverse pregnancy outcomes such as miscarriage in their female partners.

Although we did not find $W$. chondrophila in the semen of patients included in this study, we detected the presence of Chlamydiales DNA in $2.4 \%$ of samples $(n=6)$. Of note, the majority of these patients $(n=5)$, had abnormal spermiograms. Given that the detected sequences belonged to previously uncultured Chlamydiales, the role of these isolates in semen colonization warrants further investigation, including isolation and assessment of the impact on spermatozoa physiology.

Interestingly, W. chondrophila serology was significantly higher in patients above the age of 30, meaning that the risk of infection may increase with age. Compared to our previous study on healthy Swiss males, in which the mean age was $20.6 \pm 1.4$ and $W$. chondrophila seropositivity was $13.7 \%$ [24], the 
high seroprevalence observed in men of infertile couples may suggest a deleterious immunological role of $W$. chondrophila on male fertility. Similarly to what has been described earlier [21], the immunological response against $W$. chondrophila may involve the induction of an autoimmune response against an epitope shared by the bacteria and spermatozoa/ova antigens. Alternatively, a transient negative effect on male infertility may be observed only during an ongoing infection.

Overall, the high W. chondrophila seroprevalence indicates frequent exposure of men to this bacterium in Western Switzerland. Therefore, further studies are required to understand the impact of this bacterium on human health.

Author Contributions: M.S. and D.B. conceived the experimental design. D.B., N.V., M.V.M.Z., M.V., and M.S. performed the experiments. D.B. and M.S. interpreted the data. D.B., N.V., G.G., M.V., and M.S. prepared the manuscript. All authors read and approved the final manuscript.

Funding: This work was supported by the Department of Obstetrics and Gynecology, Lausanne University Hospital, Switzerland and by the Swiss National Science Foundation grant numbers 310030-156169/1, 320030-169853/1, and 320030-169853/2 attributed to David Baud. David Baud is also supported by the "Fondation Leenaards" through the "Bourse pour la relève académique", by the "Fondation Divesa", and by the "Loterie Romande".

Conflicts of Interest: The authors declare no conflict of interest.

\section{References}

1. Osser, S.; Liedholm, P.; Ranstam, J. Depressed semen quality: A study over two decades. Arch. Androl. 1984, 12, 113-116. [CrossRef] [PubMed]

2. Menkveld, R.; Van Zyl, J.A.; Kotze, T.J.; Joubert, G. Possible changes in male fertility over a 15-year period. Arch. Androl. 1986, 17, 143-144. [CrossRef] [PubMed]

3. Gimenes, F.; Souza, R.P.; Bento, J.C.; Teixeira, J.J.V.; Maria-Engler, S.S.; Bonini, M.G.; Consolaro, M.E.L. Male infertility: A public health issue caused by sexually transmitted pathogens. Nat. Rev. Urol. 2014, 11, 672-687. [CrossRef] [PubMed]

4. Rozati, R.; Reddy, P.P.; Reddanna, P.; Mujtaba, R. Role of environmental estrogens in the deterioration of male factor fertility. Fertil. Steril. 2002, 78, 1187-1194. [CrossRef]

5. Choy, J.T.; Eisenberg, M.L. Male infertility as a window to health. Fertil. Steril. 2018, 110, 810-814. [CrossRef] [PubMed]

6. Weidner, W.; Pilatz, A.; Diemer, T.; Schuppe, H.C.; Rusz, A.; Wagenlehner, F. Male urogenital infections: Impact of infection and inflammation on ejaculate parameters. World J. Urol. 2013, 31, 717-723. [CrossRef]

7. La Vignera, S.; Condorelli, R.A.; Vicari, E.; Salmeri, M.; Morgia, G.; Favilla, V.; Cimino, S.; Calogero, A.E. Microbiological investigation in male infertility: A practical overview. J. Med. Microbiol. 2014, 63, 1-14. [CrossRef]

8. Shang, Y.; Liu, C.; Cui, D.; Han, G.; Yi, S. The effect of chronic bacterial prostatitis on semen quality in adult men: A meta-analysis of case-control studies. Sci. Rep. 2014, 4, 7233. [CrossRef]

9. Erbengi, T. Ultrastructural observations on the entry of Chlamydia trachomatis into human spermatozoa. Hum. Reprod. 1993, 8, 416-421. [CrossRef]

10. Dehghan Marvast, L.; Talebi, A.R.; Ghasemzadeh, J.; Hosseini, A.; Pacey, A.A. Effects of Chlamydia trachomatis infection on sperm chromatin condensation and DNA integrity. Andrologia 2018, 50, e12918. [CrossRef]

11. Satta, A. Experimental Chlamydia trachomatis infection causes apoptosis in human sperm. Hum. Reprod. 2005, 21, 134-137. [CrossRef] [PubMed]

12. Al-Mously, N.; Cross, N.A.; Eley, A.; Pacey, A.A. Real-time polymerase chain reaction shows that density centrifugation does not always remove Chlamydia trachomatis from human semen. Fertil. Steril. 2009, 92, 1606-1615. [CrossRef] [PubMed]

13. Baud, D.; Vulliemoz, N.; Ammerdorffer, A.; Gyger, J.; Greub, G.; Castella, V.; Stojanov, M. Waddlia chondrophila, a Chlamydia-related bacterium, has a negative impact on human spermatozoa. Hum. Reprod. 2017, 33, 3-10. [CrossRef] [PubMed] 
14. Henning, K.; Schares, G.; Granzow, H.; Polster, U.; Hartmann, M.; Hotzel, H.; Sachse, K.; Peters, M.; Rauser, M. Neospora caninum and Waddlia chondrophila strain 2032/99 in a septic stillborn calf. Vet. Microbiol. 2002, 85, 285-292. [CrossRef]

15. Dilbeck, P.M.; Evermann, J.F.; Crawford, T.B.; Ward, A.C.; Leathers, C.W.; Holland, C.J.; Mebus, C.A.; Logan, L.L.; Rurangirwa, F.R.; McGuire, T.C. Isolation of a previously undescribed rickettsia from an aborted bovine fetus. J. Clin. Microbiol. 1990, 28, 814-816. [CrossRef]

16. Baud, D.; Thomas, V.; Arafa, A.; Regan, L.; Greub, G. Waddlia chondrophila, a potential agent of human fetal death. Emerg. Infect. Dis. 2007, 13, 1239. [CrossRef]

17. Baud, D.; Goy, G.; Osterheld, M.-C.; Croxatto, A.; Borel, N.; Vial, Y.; Pospischil, A.; Greub, G. Role of Waddlia chondrophila placental infection in miscarriage. Emerg. Infect. Dis. 2014, 20,460-464. [CrossRef]

18. Hornung, S.; Thuong, B.C.; Gyger, J.; Kebbi-Beghdadi, C.; Vasilevsky, S.; Greub, G.; Baud, D. Role of Chlamydia trachomatis and emerging Chlamydia-related bacteria in ectopic pregnancy in Vietnam. Epidemiol. Infect. 2015, 143, 2635-2638. [CrossRef]

19. Croxatto, A.; Greub, G. Early intracellular trafficking of Waddlia chondrophila in human macrophages. Microbiology 2010, 156, 340-355. [CrossRef]

20. Kebbi-Beghdadi, C.; Cisse, O.; Greub, G. Permissivity of Vero cells, human pneumocytes and human endometrial cells to Waddlia chondrophila. Microbes Infect. 2011, 13, 566-574. [CrossRef]

21. Baud, D.; Regan, L.; Greub, G. Emerging role of Chlamydia and Chlamydia-like organisms in adverse pregnancy outcomes. Curr. Opin. Infect. Dis. 2008, 21, 70-76. [CrossRef] [PubMed]

22. Goy, G.; Croxatto, A.; Posfay-Barbe, K.M.; Gervaix, A.; Greub, G. Development of a real-time PCR for the specific detection of Waddlia chondrophila in clinical samples. Eur. J. Clin. Microbiol. Infect. Dis. 2009, 28, 1483-1486. [CrossRef] [PubMed]

23. Lienard, J.; Croxatto, A.; Aeby, S.; Jaton, K.; Posfay-Barbe, K.; Gervaix, A.; Greub, G. Development of a New Chlamydiales-Specific Real-Time PCR and Its Application to Respiratory Clinical Samples. J. Clin. Microbiol. 2011, 49, 2637-2642. [CrossRef] [PubMed]

24. Baud, D.; Kebbi, C.; Külling, J.-P.; Greub, G. Seroprevalence of different Chlamydia-like organisms in an asymptomatic population. Clin. Microbiol. Infect. 2009, 15 (Suppl. 2), 213-215. [CrossRef]

25. Vouga, M.; Kebbi-Beghdadi, C.; Liénard, J.; Baskin, L.; Baud, D.; Greub, G. What is the true clinical relevance of Simkania negevensis and other emerging Chlamydiales members? New Microbes New Infect. 2018, 23, 1-5. [CrossRef]

26. Joki-Korpela, P.; Sahrakorpi, N.; Halttunen, M.; Surcel, H.-M.; Paavonen, J.; Tiitinen, A. The role of Chlamydia trachomatis infection in male infertility. Fertil. Steril. 2009, 91, 1448-1450. [CrossRef]

27. Eggert-Kruse, W.; Rohr, G.; Demirakca, T.; Rusu, R.; Näher, H.; Petzoldt, D.; Runnebaum, B. Chlamydial serology in 1303 asymptomatic subfertile couples. Hum. Reprod. 1997, 12, 1464-1475. [CrossRef]

28. Close, C.E.; Wang, S.P.; Roberts, P.L.; Berger, R.E. The relationship of infection with Chlamydia trachomatis to the parameters of male fertility and sperm autoimmunity. Fertil. Steril. 1987, 48, 880-883. [CrossRef]

29. Mackern-Oberti, J.P.; Motrich, R.D.; Breser, M.L.; Sánchez, L.R.; Cuffini, C.; Rivero, V.E. Chlamydia trachomatis infection of the male genital tract: An update. J. Reprod. Immunol. 2013, 100, 37-53. [CrossRef]

30. Eley, A.; Hosseinzadeh, S.; Hakimi, H.; Geary, I.; Pacey, A.A. Apoptosis of ejaculated human sperm is induced by co-incubation with Chlamydia trachomatis lipopolysaccharide. Hum. Reprod. 2005, 20, 2601-2607. [CrossRef]

31. Eley, A.; Pacey, A.A.; Galdiero, M.; Galdiero, M.; Galdiero, F. Can Chlamydia trachomatis directly damage your sperm? Lancet Infect. Dis 2005, 5, 53-57. [CrossRef]

32. Hosseinzadeh, S.; Eley, A.; Pacey, A.A. Semen quality of men with asymptomatic chlamydial infection. J. Androl. 2004, 25, 104-109. [CrossRef] [PubMed]

(C) 2020 by the authors. Licensee MDPI, Basel, Switzerland. This article is an open access article distributed under the terms and conditions of the Creative Commons Attribution (CC BY) license (http://creativecommons.org/licenses/by/4.0/). 